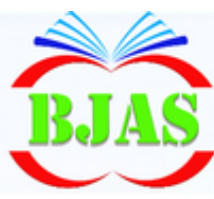

ISSN $1814-5868$
Available online at http://bjas.bajas.edu.iq

https://doi.org/10.37077/25200860.2020.33.2.08

College of Agriculture, University of Basrah

\title{
Effect of Spraying of Organic Fertilizers (ALGAZON) and Dry Yeast Extract on some Vegetative Parameters and the Yield of Volatile Oil and its Qualities of Myrtus (Myrtus communis L.)
}

\section{Basrah Journal of Agricultural Sciences}

E-ISSN: 2520-0860

Basrah J. Agric. Sci., 33(2): 95-105, 2020

(n) 
restraint and tissue culture (Ebrahimabadi et al., 2016).

Seaweed extract is one of the most important recently used organic fertilizers, to improve plant growth with high efficiency and less pollution to the environment, Including Algazon extract, which is extract from algae brown Ascophyllum nodosum, belongs to the Fucaceae family, characterized by its dark colour, which ranges between brown and almost black, this is due to high content of humic compounds such as polyphenols (Al-Janabi \& Al-Shabani, 2017), so it is one of the organic fertilizers that nourish the plant, contains major, minor and rare elements, such as $\mathrm{N}, \mathrm{K}, \mathrm{P}, \mathrm{Co}, \mathrm{Mg}, \mathrm{Br}$, $\mathrm{Mo}, \mathrm{Zn}, \mathrm{Cu}$, and $\mathrm{Fe}$ (Eyras et al., 2008).

Salman \& Sachet (2013) they found when spraying the dill plant grown in Babel governorate with liquid organic fertilizer, at a concentration of $6 \mathrm{ml} \mathrm{L}^{-1}$, resulted in a significant increase in the yield of volatile oil, oil productivity per unit area, oil density and refractive index, compared to plant not sprayed. Matroad et al. (2016) showed that the spraying Ocimum basilicum L basil plants, Kelpak seaweed extract, at a concentration of 0 and $2 \mathrm{ml}$. $\mathrm{L}^{-1}$, results showed that a significant effect, plants sprayed with seaweed extract at a concentration of $2 \mathrm{ml} . \mathrm{L}^{-1}$ were significantly increasing the percentage of oil, yield of one plant, productivity per hectare of oil, and the specific density of essential oil, compared to plants that have been sprayed with distilled water only.

Dry yeast extract Saccharomyces cerevisiae of biological stimuli and natural biological fertilizers, promoted to improvement plant growth and its quality (Abd El-Motty et al., 2010), they are eukaryotic organisms, belongs to the Saccharomycetaceae family, within the
Division of Cystic Fungi Ascomycetes, considered from the organic sources, to agricultural production improve, a supplement to fertilizers. Al-Samaraee et al. (2011) showed that the treatment with activated yeast suspension at 2 g..$^{-1}$ caused a significant increase in plant height, number of lateral branches, and number of leaves, compare with yeast suspension at $1 \mathrm{~g}$. $\mathrm{L}$ and the control. Al-Doghachi et al. (2012) report that leave and soils praying with active dry yeast extracts were a significantly improved on some traits of Cumin plant Cuminum cyminum L..

The medical importance of plant, experiment was conducted to determine the effect of best concentration of organic fertilizer (Algazon) and dry yeast extract, to improving the vegetative growth and the yield of volatile of myrtus plant.

\section{Materials \& Methods}

This study was conducted at the nursery of Agricultural Research Station, Agriculture College, University of Basrah, Qarmat Ali campus, for the agricultural season 20182019 , to determine the effect of spraying of organic fertilizers (ALGAZON) and dry yeast extract on some vegetative parameters and the yield of volatile of Myrtus (Myrtus communis L.). Brought the plants from one of the private nurseries in Basrah on 5/9/2018, Plant age was two years old, transported to large size plastic pots, $30 \mathrm{~cm}$ in diameter and $30 \mathrm{~cm}$ in depth, capacity of $12.5 \mathrm{~kg}$ of soil with peat moss, in a ratio of $1: 2$, the height of the plants was standardized to $55 \mathrm{~cm}$, leaving 5 branches. Plant ${ }^{-1}$ at 17/9/2018. Random samples were taken from This mixture to analyze some of its chemical and physical properties, as well as analysis of watering samples in the central laboratory of 
Agriculture College, University of Basrah were done (Tables 1 and 2).

Table (1): Some physical and chemical properties of the soil used in the study.

\begin{tabular}{cc}
\hline Properties & Value \\
\hline Electrical Conductivity (ds.m-1) & 1.53 \\
\hline $\mathrm{pH}$ & 7.49 \\
\hline Total nitrogen (mg. L-1) & 0.87 \\
\hline Available phosphorus & 17.75 \\
\hline Available potassium & 22.15 \\
\hline Organic matter (\%) & 0.42 \\
\hline Physical soil properties (\%) \\
\hline Sand \\
\hline Silt & 50.94 \\
\hline Clay & 29.05 \\
\hline Soil texture & 20.01 \\
\hline
\end{tabular}

Table (2): Some chemical properties of the irrigation water used in the study.

\begin{tabular}{|c|c|}
\hline Properties & Value \\
\hline $\mathrm{pH}$ & 7.6 \\
\hline Bicarbonate & $41.2 \mathrm{mg} . \mathrm{L}^{-1}(\mathrm{ppm})$ \\
\hline Sulphate & $18.3 \mathrm{mg} . \mathrm{L}^{-1}$ \\
\hline Sodium & $21.9 \mathrm{mg} . \mathrm{L}^{-1}$ \\
\hline Calcium & $3.6 \mathrm{mg} . \mathrm{L}^{-1}$ \\
\hline Magnesium & $19.0{\mathrm{mg} . \mathrm{L}^{-1}}^{-1}$ \\
\hline Potassium & $1.00 \mathrm{mg} . \mathrm{L}^{-1}$ \\
\hline Chloride & $50.2 \mathrm{mg} . \mathrm{L}^{-1}$ \\
\hline Fluoride & $0.02 \mathrm{mg} . \mathrm{L}^{-1}$ \\
\hline Nitrate & $6.8 \mathrm{mg} . \mathrm{L}-1$ \\
\hline
\end{tabular}

Experiment was conducted using Randomized Complete Block Design (R.C.B.D), with two factors, in three replicates (the experimental unit includes 6 plants), First Algazon marine algae extract were used, extracted from brown seaweed (Ascceufelume nodosum), production in Aljoud Company, a subsidiary of the Iraqi Alkafeel company, components were described in table (3), sprayed in three concentrations $0,1.5$ and $3 \mathrm{ml} . \mathrm{L}^{-1}$, and dry yeast extract components were described in table (4), with concentrations (0, 3 and 6) $\mathrm{g}$. $\mathrm{L}^{-1}$, dry yeast extract was prepared, by melt 3 and $6 \mathrm{~g}$ separately in a liter of warm distilled water, at a temperature of $32{ }^{\circ} \mathrm{C}$, with addition of $1 \mathrm{~g}$ of sugar (sucrose) to activate the yeast. Sprinkle myrtus vegetables with Algazon fertilizer and dry Yeast Extract at the required concentrations, in the early morning until completely wet, an average of five sprinkles from one sprinkle to another 30 days, starting from 17 October 2018, a fiveday difference between the factors (Table 5.). 
Salih et al./ Basrah J. Agric. Sci., 33 (2): 95-105, 2020

Table (3): Some components of Algazon seaweed extract used in the study.

Organic fertilizer

(Algazon)

Extract $(\%)$

Organic fertilizer (Algazon)

Extract

Composition

Composition

$(\%)$

\begin{tabular}{cccc}
\hline $\mathrm{N}$ & 7.80 & Indole acetic acid & 0.002 \\
\hline $\mathrm{P}$ & 3.90 & Phosphorus oxide $\mathrm{p}_{20}$ 5 & 0.5 \\
\hline $\mathrm{K}$ & 13 & Alanine & 0.026 \\
\hline $\mathrm{MO}$ & 0.4 & Phytin & 0.003 \\
\hline $\mathrm{Fe}$ & 0.1 & Menthol & 0.001 \\
\hline $\mathrm{Zn}$ & 0.5 & Organic matter & 6 \\
\hline $\mathrm{K}_{2} \mathrm{O}$ & $4 \%$ & Carbohydrate and Vitamins & $16-12 \%$ \\
\hline $\mathrm{Mg}$ & $32 \mathrm{ppm}$ & Glytamic acid & 0.0019 \\
\hline $\mathrm{Mn}$ & $31 \mathrm{ppm}$ & Fats & $7-11 \%$ \\
\hline $\mathrm{Cu}$ & $12.6 \mathrm{ppm}$ & Auxins, cytokinins and gibberlins & $28-32 \%$ \\
\hline & & Proteinz & $50-55 \%$ \\
\hline
\end{tabular}

Table (4): Some dry yeast components used in the study for the 2018-2019_season.

\begin{tabular}{|c|c|c|c|c|c|}
\hline Amino acids & $\begin{array}{c}\text { Value } \\
\left(\mathrm{mg} \cdot \mathrm{g}^{-1}\right)\end{array}$ & $\begin{array}{l}\text { Mineral } \\
\text { elements }\end{array}$ & $\begin{array}{l}\text { Value } \\
\text { (mg. g) }\end{array}$ & Nucleic acids & $\begin{array}{l}\text { Value } \\
\text { (mg. g) }\end{array}$ \\
\hline Glycine & 0.103 & $\mathrm{P}$ & 12.50 & Adenine & 5.48 \\
\hline Alanine & 0.132 & $\mathrm{~K}$ & 30 & Guanine & 5.66 \\
\hline Isoleucine & 0.421 & $\mathrm{Na}$ & 56 & Xanthine & 3.25 \\
\hline Aspartic acid & 0.274 & $\mathrm{Mg}$ & 2 & Cytosine & 3.31 \\
\hline Glutamic acid & 0.367 & $\mathrm{Ca}$ & 0.1 & Uracil+Thymine & 5.97 \\
\hline Serine & 0.523 & $\mathrm{Mn}$ & 5.69 & $\begin{array}{c}\text { Another } \\
\text { components }\end{array}$ & $\begin{array}{c}\text { Value } \\
\left(\mathrm{mg} \cdot \mathrm{g}^{-1}\right)\end{array}$ \\
\hline Threonine & 0.206 & $\mathrm{Zn}$ & 69.5 & Total Nitrogen & 90 \\
\hline Tyrosine & 0.031 & $\mathrm{Cu}$ & 0.02 & Carbohydrate & 82 \\
\hline $\begin{array}{l}\text { Phenyl } \\
\text { alanine }\end{array}$ & 0.116 & $\mathrm{Fe}$ & 0.05 & Ash & 10.51 \\
\hline Proline & 0.041 & Co & 0.005 & Water & 5.0 \\
\hline Arginine & 0.073 & Vitamins & $\begin{array}{c}\text { Value } \\
\left(\mathrm{mg} \cdot \mathrm{g}^{-1}\right)\end{array}$ & Chlorides & 13.1 \\
\hline Lysine & 0.089 & Vit. B1 & 28.1 & Phosphate & 38 \\
\hline Cysteine & 0.025 & Vit. B2 & 31.7 & $\begin{array}{l}\text { Amino acid } \\
\text { nitrogen }\end{array}$ & 40 \\
\hline Methionine & 0.012 & Vit,B6 & 46.1 & $\begin{array}{c}\text { Natural growth } \\
\text { regulators }\end{array}$ & - \\
\hline Tryptophan & 0.020 & $\begin{array}{c}\text { Pantothenic } \\
\text { acid }\end{array}$ & 52.5 & & \\
\hline \multirow[t]{3}{*}{ Leucine } & 0.067 & Biotin & 1.6 & & \\
\hline & & Niacin & 5.3 & & \\
\hline & & Inositol & 33.9 & & \\
\hline
\end{tabular}


Salih et al./ Basrah J. Agric. Sci., 33 (2): 95-105, 2020

Table (5): Number and timing of sprinkles for each factor of the study.

\begin{tabular}{ccc}
\hline Sprinkles & Extract & Spraying date \\
\hline \multirow{2}{*}{ First spraying } & Algazon seaweed extract & $17 / 10 / 2018$ \\
\cline { 2 - 3 } & Dry yeast extract & $21 / 10 / 2018$ \\
\hline \multirow{2}{*}{ Second spraying } & Algazon seaweed extract & $17 / 11 / 2018$ \\
\cline { 2 - 3 } & Dry yeast extract & $21 / 11 / 2018$ \\
\hline \multirow{2}{*}{ Third spraying } & Algazon seaweed extract & $17 / 12 / 2018$ \\
\cline { 2 - 3 } & Dry yeast extract & $21 / 12 / 2018$ \\
\hline \multirow{2}{*}{ Forth spraying } & Algazon seaweed extract & $17 / 1 / 2019$ \\
\cline { 2 - 3 } & Dry yeast extract & $21 / 1 / 2019$ \\
\hline \multirow{2}{*}{ Fifth spraying } & Algazon seaweed extract & $17 / 2 / 2019$ \\
\cline { 2 - 3 } & Dry yeast extract & $21 / 2 / 2019$ \\
\hline
\end{tabular}

An 8- litres manual sprinkler was used, after adding the spreader (Tween- 20) at a concentration of $0.01 \%$ of the spray solutions, for reducing surface tension and increasing the adhesion of this material to the leaves.

The data were statistically analyzed by the GenStat statistical program, the significant differences between the averages were compared with Modified Less Significant Difference (LSD) test with at probability level 0.05 (Al-Rawi \& Khalaf-Allah, 2000). The vegetative growth parameters were studied, includes plant height $(\mathrm{cm})$, stem diameter $(\mathrm{mm})$, leaf area $\left(\mathrm{cm}^{2}\right)$, main branches number (plant. branch ${ }^{-1}$ ), fresh and dry weight of leaves $(\mathrm{g})$, percentage of dry matter in leaves $(\%)$, oil percentage $(\%)$, oil yield $(\mathrm{g})$ and volatile oil per hectares (kg). Physical parameters were measured, includes refractive index, specific weight and specific density (mg. $\mu \mathrm{L}^{-1}$ ) of oils.

\section{Results}

Table (6) shows that, a significant increased when spray with the organic fertilizer extract, Algazon, at a concentration of $3 \mathrm{ml} . \mathrm{L}^{-1}$ on plant height, main stem diameter, the leaf area, the branches number, the fresh and dry weight of the leaves and the percentage of dry matter, the highest values of $87.54 \mathrm{~cm}, 13.13$ $\mathrm{mm}, 8.77 \mathrm{~cm}^{2}, 10.85$ branches. plant ${ }^{-1}, 442.0$ $\mathrm{g}, \quad 95.55 \mathrm{~g}$, and $21.52 \%$, respectively, compared with the control treatment, which gave the lowest values as they reached 74.55 $\mathrm{cm}, 8.31 \mathrm{~mm}, 5.11 \mathrm{~cm}^{2}, 7.04$ branches. plant 1, 1344.70 g., $69.77 \mathrm{~g}$ and 19.94\%, respectively. As for the effect of dry yeast extract on vegetative growth, the results showed that the plants sprayed with dry yeast extract $6 \mathrm{~g}$. $\mathrm{L}^{-1}$ were a significant exceeded on the plant height, gave the highest value of $90.31 \mathrm{~cm}$, compare with all other concentrations and control plants, which gave the lowest value was $71.11 \mathrm{~cm}$, the yeast extract at a concentration of $6 \mathrm{~g}$. $\mathrm{L}^{-1}$ was a significant increase on the stem diameter, reached $11.37 \mathrm{~mm}$, compared to the control treatment, which gave the lowest stem diameter of $9.32 \mathrm{~mm}$, the effect of yeast extract with concentration $6 \mathrm{~g}$. $\mathrm{L}^{-1}$ was significant increase, in the leaf area, the branches number, the fresh and dry weight of the vegetative group and the percentage of dry matter, recorded the highest values of 7.61 $\mathrm{cm}^{2}, 10.85$ branches. plant ${ }^{-1}, 406.23 \mathrm{~g}, 85.81$ $\mathrm{g}$ and $20.89 \%$, respectively, compared to the control treatment, the lowest values were recorded $6.58 \mathrm{~cm}^{2}, 6.41$ branches. plant ${ }^{-1}$, $366.80 \mathrm{~g}, 75.32 \mathrm{~g}$ and $20.31 \%$, respectively. 
Table (6): The effect of spraying of organic fertilizers (ALGAZON) and dry yeast extract on some vegetative parameters of Myrtus (Myrtus communis L.) for the season 2018-2019 (Means \pm Standard error).

\begin{tabular}{|c|c|c|c|c|c|c|c|c|}
\hline $\begin{array}{l}\text { Organic Fertilizer conc. } \\
\qquad\left(\mathrm{ml}^{\left.-\mathrm{L}^{-1}\right)}\right.\end{array}$ & $\begin{array}{l}\text { Yeast } \\
\text { conc. } \\
\left(\text { g. } L^{-1}\right)\end{array}$ & $\begin{array}{l}\text { plant } \\
\text { height } \\
(\mathrm{cm})\end{array}$ & $\begin{array}{c}\text { stem } \\
\text { diameter } \\
(\mathrm{mm})\end{array}$ & $\begin{array}{l}\text { leaf area } \\
\left(\mathrm{cm}^{2}\right)\end{array}$ & $\begin{array}{c}\text { main } \\
\text { branches } \\
\text { number } \\
\text { (plant. } \text { branch }^{-1} \text { ) }\end{array}$ & $\begin{array}{l}\text { fresh weight } \\
\text { of leaves }(\mathrm{g})\end{array}$ & $\begin{array}{l}\text { dry weight } \\
\text { of leaves }(\mathrm{g})\end{array}$ & $\begin{array}{l}\text { percentage } \\
\text { of dry } \\
\text { matter }(\%)\end{array}$ \\
\hline \multirow{3}{*}{0} & 0 & $65.27 \pm 3.2 \mathrm{c}$ & $7.67 \pm 0.16 b$ & $4.53 \pm 0.09 c$ & $5.78 \pm 0.07 \mathrm{c}$ & $327.0 \pm 17.2 \mathrm{c}$ & $66.50 \pm 5.3 c$ & $19.80 \pm 0.22 b$ \\
\hline & 3 & $73.36 \pm 1.2 \mathrm{~b}$ & $7.83 \pm 0.09 \mathrm{~b}$ & $4.90 \pm 0.10 \mathrm{~b}$ & $6.44 \pm 0.11 b$ & $337.5 \pm 20.4 b$ & $67.71 \pm 5.7 b$ & $19.85 \pm 0.17 b$ \\
\hline & 6 & $85.03 \pm 5.4 \mathrm{a}$ & $9.43 \pm 0.14 a$ & $5.90 \pm 0.07 \mathrm{a}$ & $8.89 \pm 0.08 \mathrm{a}$ & $369.5 \pm 19.2 \mathrm{a}$ & $75.12 \pm 4.8 \mathrm{a}$ & $20.18 \pm 0.11 \mathrm{a}$ \\
\hline \multirow{3}{*}{1.5} & 0 & $70.00 \pm 4.8 \mathrm{c}$ & $8.24 \pm 0.11 \mathrm{c}$ & $6.85 \pm 0.11 \mathrm{~b}$ & $5.89 \pm 0.05 c$ & $353.9 \pm 16.4 \mathrm{c}$ & $71.10 \pm 6.2 \mathrm{c}$ & $20.14 \pm 0.09 b$ \\
\hline & 3 & $78.02 \pm 2.7 \mathrm{~b}$ & $9.00 \pm 0.05 b$ & $7.38 \pm 0.07 \mathrm{a}$ & $7.00 \pm 0.07 \mathrm{~b}$ & $359.1 \pm 11.6 b$ & $73.91 \pm 5.9 \mathrm{~b}$ & $20.25 \pm 0.16 b$ \\
\hline & 6 & $88.02 \pm 4.3 \mathrm{a}$ & $10.60 \pm 0.06 \mathrm{a}$ & $7.78 \pm 0.22 \mathrm{a}$ & $9.78 \pm 0.09 a$ & $379.3 \pm 15.4 \mathrm{a}$ & $78.77 \pm 7.1 \mathrm{a}$ & $20.54 \pm 0.14 a$ \\
\hline \multirow{3}{*}{3} & 0 & $78.04 \pm 2.3 \mathrm{c}$ & $12.06 \pm 0.11 \mathrm{c}$ & $8.36 \pm 0.18 \mathrm{~b}$ & $7.56 \pm 0.07 \mathrm{c}$ & $419.3 \pm 12.7 \mathrm{c}$ & $88.37 \pm 6.6 \mathrm{c}$ & $21.00 \pm 0.15 \mathrm{c}$ \\
\hline & 3 & $86.695 .5 b$ & $13.27 \pm 0.11 \mathrm{~b}$ & $8.79 \pm 0.25 b$ & $9.11 \pm 0.05 \mathrm{~b}$ & $436.7 \pm 22.7 b$ & $94.72 \pm 7.0 \mathrm{~b}$ & $21.61 \pm 0.09 b$ \\
\hline & 6 & $97.89 \pm 3.4 \mathrm{a}$ & $14.08 \pm 0.06 \mathrm{a}$ & $9.14 \pm 0.20 \mathrm{a}$ & $13.89 \pm 0.19 \mathrm{a}$ & $469.9 \pm 25.2 \mathrm{a}$ & $103.55 \pm 4.2 \mathrm{a}$ & $21.96 \pm 0.10 \mathrm{a}$ \\
\hline L.S.D 0.05 & & 2.020 & 7.67 & 0.5353 & 0.5846 & 11.92 & 1.583 & 0.4828 \\
\hline \multirow{3}{*}{ Organic Fertilizer means } & 0 & $74.55 \pm 2.7 \mathrm{c}$ & $8.31 \pm 0.05 b$ & $5.11 \pm 0.07 \mathrm{c}$ & $7.04 \pm 0.07 \mathrm{c}$ & $344.7 \pm 19.8 \mathrm{c}$ & $69.78 \pm 5.2 \mathrm{c}$ & $19.94 \pm 0.11 \mathrm{c}$ \\
\hline & 1.5 & $78.68 \pm 1.9 \mathrm{~b}$ & $9.28 \pm 0.04 b$ & $7.34 \pm 0.11 \mathrm{~b}$ & $7.56 \pm 0.08 b$ & $364.1 \pm 20.4 b$ & $74.59 \pm 5.8 \mathrm{~b}$ & $20.31 \pm 0.13 b$ \\
\hline & 3 & $87.54 \pm 2.4 \mathrm{a}$ & $13.13 \pm 0.07 \mathrm{a}$ & $8.77 \pm 0.09 a$ & $10.19 \pm 0.11 \mathrm{a}$ & $442.0 \pm 23.1 \mathrm{a}$ & $95.55 \pm 6.6 \mathrm{a}$ & $21.52 \pm 0.07 \mathrm{a}$ \\
\hline L.S.D 0.05 & & 1.194 & 0.01238 & 0.3093 & 0.3378 & 6.88 & 0.915 & 0.278 \\
\hline \multirow{3}{*}{ Yeast treatment means } & 0 & $71.11 \pm 3.6 \mathrm{c}$ & $9.32 \pm 0.06 \mathrm{c}$ & $6.58 \pm 0.05 \mathrm{c}$ & $6.41 \pm 0.05 c$ & $366.8 \pm 21.0 \mathrm{c}$ & $75.32 \pm 4.3 \mathrm{c}$ & $20.31 \pm 0.15 b$ \\
\hline & 3 & $79.36 \pm 3.3 b$ & $10.03 \pm 0.05 b$ & $7.02 \pm 0.06 \mathrm{~b}$ & $7.52 \pm 0.08 b$ & $377.8 \pm 19.2 b$ & $78.78 \pm 3.2 b$ & $20.57 \pm 0.14 b$ \\
\hline & 6 & $90.31 \pm 6.1 \mathrm{a}$ & $11.37 \pm 0.05 \mathrm{a}$ & $7.61 \pm 0.05 \mathrm{a}$ & $10.85 \pm 0.11 \mathrm{a}$ & $406.2 \pm 21.2 \mathrm{a}$ & $85.81 \pm 5.4 \mathrm{a}$ & $20.89 \pm 0.12 a$ \\
\hline L.S.D 0.05 & & 1.196 & 0.01235 & 0.3090 & 0.3374 & 6.88 & 0.913 & 0.2787 \\
\hline
\end{tabular}

Means followed by the same letters are not significantly different $(\mathrm{P}<0.05)$ according to modified L.S.D test . 
Table (7): The effect of spraying of organic fertilizers (ALGAZON) and dry yeast extract on availability of volatile oil and Physical parameters of Myrtus (Myrtus communis L.) for the season 2018-2019.

\begin{tabular}{|c|c|c|c|c|c|c|c|}
\hline $\begin{array}{l}\text { Organic Fertilizer conc. } \\
\qquad\left(\mathrm{ml}^{\mathrm{L}} \mathrm{L}^{-1}\right)\end{array}$ & $\begin{array}{l}\text { Yeast conc. } \\
\qquad\left(\mathrm{g} . \mathrm{L}^{-1}\right)\end{array}$ & $\begin{array}{c}\text { Oil } \\
\text { percentage } \\
(\%)\end{array}$ & Oil yield $(\mathrm{g})$ & $\begin{array}{l}\text { Volatile oil } \\
\text { per hectares } \\
\quad(\mathrm{kg})\end{array}$ & $\begin{array}{l}\text { Refractive } \\
\text { index }\end{array}$ & $\begin{array}{c}\text { Specific } \\
\text { weight }\end{array}$ & $\begin{array}{l}\text { Density } \\
\text { (mg. } \mu \mathrm{L}^{-1} \text { ) }\end{array}$ \\
\hline \multirow{3}{*}{0} & 0 & $0.396 \pm 0.001 c$ & $0.265 \pm 0.001 \mathrm{c}$ & $14.73 \pm 0.08 \mathrm{a}$ & $1.470 \pm 0.02$ & $0.748 \pm 0.005 \mathrm{c}$ & $0.748 \pm 0.006 c$ \\
\hline & 3 & $0.403 \pm 0.002 b$ & $0.277 \pm 0.001 b$ & $15.382 \pm 0.11 \mathrm{~b}$ & $1.471 \pm 0.01$ & $0.762 \pm 0.006 b$ & $0.757 \pm 0.004 b$ \\
\hline & 6 & $0.414 \pm 0.001 \mathrm{a}$ & $0.313 \pm 0.001 \mathrm{a}$ & $17.407 \pm 0.09 \mathrm{c}$ & $1.472 \pm 0.01$ & $0.798 \pm 0.001 \mathrm{a}$ & $0.772 \pm 0.005 \mathrm{a}$ \\
\hline \multirow{3}{*}{1.5} & 0 & $0.419 \pm 0.001 b$ & $0.301 \pm 0.001 \mathrm{~b}$ & $16.727 \pm 0.12 \mathrm{a}$ & $1.471 \pm 0.03$ & $0.766 \pm 0.009 \mathrm{c}$ & $0.754 \pm 0.005 c$ \\
\hline & 3 & $0.417 \pm 0.003 b$ & $0.311 \pm 0.001 \mathrm{~b}$ & $17.271 \pm 0.11 \mathrm{~b}$ & $1.472 \pm 0.01$ & $0.781 \pm 0.007 b$ & $0.757 \pm 0.004 b$ \\
\hline & 6 & $0.426 \pm 0.001 \mathrm{a}$ & $0.338 \pm 0.002 \mathrm{a}$ & $18.758 \pm 0.09 \mathrm{c}$ & $1.472 \pm 0.02$ & $0.805 \pm 0.006 \mathrm{a}$ & $0.804 \pm 0.005 a$ \\
\hline \multirow{3}{*}{3} & 0 & $0.444 \pm 0.003 b$ & $0.394 \pm 0.001 \mathrm{c}$ & $21.913 \pm 0.14 \mathrm{a}$ & $1.473 \pm 0.02$ & $0.793 \pm 0.005 \mathrm{c}$ & $0.795 \pm 0.03 b$ \\
\hline & 3 & $0.450 \pm 0.002 \mathrm{a}$ & $0.428 \pm 0.001 \mathrm{~b}$ & $23.765 \pm 0.13 b$ & $1.472 \pm 0.01$ & $0.799 \pm 0.004 b$ & $0.777 \pm 0.005 \mathrm{c}$ \\
\hline & 6 & $0.454 \pm 0.002 \mathrm{a}$ & $0.473 \pm 0.002 \mathrm{a}$ & $26.260 \pm 0.09 \mathrm{c}$ & $1.473 \pm 0.02$ & $0.811 \pm 0.006 \mathrm{a}$ & $0.823 \pm 0.006 a$ \\
\hline L.S.D 0.05 & & 0.0065 & 0.0098 & 0.5503 & 0.0008 & 0.0034 & 0.0043 \\
\hline \multirow{3}{*}{ Organic Fertilizer means } & 0 & $0.404 \pm 0.002 b$ & $0.285 \pm 0.001 \mathrm{c}$ & $15.841 \pm 0.07 \mathrm{c}$ & $1.471 \pm 0.02$ & $0.769 \pm 0.006 \mathrm{c}$ & $0.759 \pm 0.004 a$ \\
\hline & 1.5 & $0.420 \pm 0.001 b$ & $0.317 \pm 0.001 b$ & $17.586 \pm 0.08 b$ & $1.472 \pm 0.01$ & $0.784 \pm 0.005 b$ & $0.771 \pm 0.003 b$ \\
\hline & 3 & $0.450 \pm 0.001 \mathrm{a}$ & $0.432 \pm 0.002 \mathrm{a}$ & $23.981 \pm 0.11 \mathrm{a}$ & $1.473 \pm 0.01$ & $0.801 \pm 0.004 a$ & $0.799 \pm 0.004 \mathrm{c}$ \\
\hline L.S.D 0.05 & & 0.0039 & 0.0059 & 0.3178 & 0.0005 & 0.0019 & 0.0025 \\
\hline \multirow{3}{*}{ Yeast treatment means } & 0 & $0.420 \pm 0.003 b$ & $0.320 \pm 0.002 \mathrm{c}$ & $17.791 \pm 0.10 \mathrm{c}$ & $1.471 \pm 0.01$ & $0.769 \pm 0.005 \mathrm{c}$ & $0.766 \pm 0.004 b$ \\
\hline & 3 & $0.423 \pm 0.001 b$ & $0.339 \pm 0.001 b$ & $18.806 \pm 0.09 \mathrm{~b}$ & $1.472 \pm 0.02$ & $0.781 \pm 0.005 b$ & $0.764 \pm 0.006 b$ \\
\hline & 6 & $0.431 \pm 0.002 \mathrm{a}$ & $0.375 \pm 0.001 \mathrm{a}$ & $20.810 \pm 0.15 a$ & $1.472 \pm 0.01$ & $0.805 \pm 0.004 a$ & $0.800 \pm 0.007 \mathrm{a}$ \\
\hline L.S.D 0.05 & & 0.0036 & 0.0057 & 0.3177 & 0.0005 & 0.0019 & 0.0025 \\
\hline
\end{tabular}


The interaction between organic fertilizer (Algazon) spray was $3 \mathrm{ml} . \mathrm{L}^{-1}$ with yeast extract $6 \mathrm{~g}$. $\mathrm{L}^{-1}$, results showed that a significant effect in an increasing the vegetative growth, as height plant, main branches number, leaf area, stem diameter, fresh and dry weight of the leaves, and the percentage of dry matter, gives the highest values of $97.89 \mathrm{~cm}, 13.89$ braches. plant ${ }^{-1}, 9.14 \mathrm{~cm}^{2}, 14.08 \mathrm{~mm}, 469.9 \mathrm{~g}, 103.55 \mathrm{~g}$ and $21.96 \%$. respectively, compared to other treatments and control plants, gave the lowest values of $65.27 \mathrm{~cm}, 5.78$ branches. plant $^{-1}, 4.53$ $\mathrm{mm}, 7.67 \mathrm{~cm} \mathrm{2,} 327.0 \mathrm{~g}, 66.50 \mathrm{~g}$, and $19.80 \%$, respectively.

Table (7) shows the effect of organic fertilizer and dry yeast extract on oil yield and its parameters, spray the plants with organic fertilizer in a concentration of $3 \mathrm{ml}$. $\mathrm{L}^{-1}$, led to a significant increase in the percentage of oil, oil yield per plant, yield per hectare of volatile oil, specific weight and oil density except the refractive index, reached $0.450 \%, 0.432 \mathrm{~g}$, $23.981 \mathrm{~kg}$. ha ${ }^{-1}, 0.801,0.799 \mathrm{mg} . \mu \mathrm{L}^{-1}, 1.473$, respectively, compared to the control treatment that gave the lowest values, it reached $0.404 \%$, $0.285 \mathrm{~g}, 15.841 \mathrm{~kg}, 0.769,0.759 \mathrm{mg} . \mu \mathrm{L}^{-1}$, 1.471 , respectively. Also the spray with dry yeast extract at $6 \mathrm{~g}$. $\mathrm{L}^{-1}$ significant affected in all oil yield and characterization except the refractive index compared with the control treatment.

Interaction between spraying with organic fertilizers extract $3 \mathrm{~m}$. $\mathrm{L}^{-1}$, and spraying with dry yeast extract $6 \mathrm{~g}$. $\mathrm{L}^{-1}$, a significant increase in the percentage and yield of the plant from the volatile oil and the yield per hectare of the volatile oil, gave the highest values of $0.454 \%$, $0.473 \mathrm{~g}, 26.26 \mathrm{~kg}$. ha ${ }^{-1}$, compared to other treatments, especially the control treatment, which recorded the lowest values, reached $0.396 \%, \quad 0.265 \mathrm{~g}$ and $14.73 \mathrm{~kg} . \mathrm{ha}^{-1}$, respectively, the physical parameters of the oil were significantly affected by interaction, sprinkle the organic fertilizer Algazon with a concentration of $3 \mathrm{ml} \mathrm{L}^{-1}$ with a dry yeast extract at a concentration of $6 \mathrm{~g}$. $\mathrm{L}^{-1}$, as the specific weight and density increased as a result of interaction, reached 0.811 and $0.823 \mathrm{mg}$. $\mu \mathrm{L}^{-1}$, respectively, compared to other and control treatment, which gave the lowest values, reached $1.470,0.748$, and $0.748 \mathrm{mg}$. $\mu \mathrm{L}^{-}$ 1 , respectively.

\section{Discussion}

This increases in plant height (table, 6) when spraying organic fertilizer extract, (Algazon), at a concentration of $3 \mathrm{ml}$. $\mathrm{L}^{-1}$ on plant height may be due to the organic fertilizer content (table 3) of the major elements ( $\mathrm{K}, \mathrm{P}$ and $\mathrm{N})$, which the plant needs in large quantities, due to their importance in the growth and development of the plant, it is involved in the formation of chlorophyll, amino acids, hormones and energy-rich compounds, increased readiness of the plant and transition to vegetative parts (Idris, 2009). May be due to the increase in the leaf area, to increase the concentration of the extract, as well as increasing the number of sprays, or may be due to the organic fertilizer content, which increases the number and elongation of cells, it is also an enzyme accompanying in the metabolism of carbohydrates and the production of energy necessary to perform vital processes in cells, which results in increased growth (Devlin \& Witham, 1993), may be due to an increase in the percentage of dry matter in the leaves, organic fertilizers contain organic acids, it is a storehouse of nutrients, which improves cation 
exchange (shipment exchange), increase the percentage of ready-made nutrients, encourages photosynthesis, and increase the accumulation of materials manufactured in the leaves such as carbohydrates and proteins, improved vegetative growth, positively affected dry weight gain (Al-Sahaf et al., 2018), or due to the organic fertilizers contained cytokines and growth stimuli, helps increase the leaf area, increase the process of photosynthesis, increases the dry matter in the leaves (Jensen, 2004).

The plants sprayed with dry yeast extract $6 \mathrm{~g}$. $\mathrm{L}^{-1}$ were a significant exceeded may be to the effect of yeast in the vegetative growth, to produce ATP and D-Ribose phosphate $-\mathrm{S}-\mathrm{S}$ energy, as well as its role in increasing the production of substances that stimulate plant growth, contains the major and minor nutrients shown in Table 4., effect of the synthesis of amino acids, helps divide and elongate cells, which reflects positively in increasing the height of the plant. (Reed \& Nagodawithana, 1991), or due to the content of yeast extract from stimulating substances for growth, such as cytokines, thiamin, niacin, riboflavin, vitamin B12 and folic acid, important for growth, represents the increase in the leaf area, positively affects the increase of photosynthesis activity, reflected positively on the vegetative system, including the number of branches (Hegazi \& Awad, 2002).

\section{Conclusions}

Results showed in this experiment, Myrtus plant's response to spraying of organic fertilizer (ALGAZON) and dry yeast extract, which reflected a positively improvement in the vegetative parameters and yield of the volatile oil and its quality.

\section{Acknowledgements}

I would like to thank to Horticulture and Landscape Gardening Department, College of Agriculture, University of Basrah for facilitating the task of laboratory analyses.

\section{Conflict of interest}

The authors declare that they have no conflict of interest photographed the samples.

\section{ORCID}

K. H. Mohammed https://orcid.org/00000003-4469-0210

\section{References}

Abd El- Motty, Z.; Shahin F.M.; El-Shiekh H. \& Abd-ElMigeed M.M. (2010). Effect of algae extract and yeast application on growth, nutritional status, yield and fruit quality of Keitte mango trees. Agriculture and Biology Journal of North America, 1, 421429.https://scihub.org/ABJNA/PDF/2010/3/1-3-421429.pdf

Al-Doghachi, E. H., Hamzaand, A. R. K., \& Essa, W. M. (2012). Physiological study of the effect spraying with seaweed extracts and addition methods of active dry yeaston vegetative and flowering growthof Cuminplant (Cuminum cyminum L.). Basrah Journal Agriculture $\quad$ Science, 25, 1-12. https://www.iasj.net/iasj?func=fulltext\&aId=54164

Al-Janabi, A. M. I., \& Al-Shabani, N. T. A. (2017). Effect of foliar application with growth regulators CPPU and seaweed extract oligo-x on some growth parameters of sour orange rootstock. Anbar Journal Agriculture $\quad$ Science, 15, 244259.https://www.iasj.net/iasj?func=article\&aId=1291 18

Al-Rawi, K. M., \& Khalaf-Allah A. M. (2000). Design and analysis of agricultural experiments. Directorate for Book House of Publishing and Pressing. University of Mosul. Ministry of Higher Education and Scientific Research. Iraq. 488pp. (In Arabic). http://web.uod.ac/documents/174/JDU-V.12-

N.1_Agri-Veter.pdf 


\section{Salih et al./ Basrah J. Agric. Sci., 33 (2): 95-105, 2020}

Al-Sahaf, F. H. R., Al-Zurfi, M. T. H., Al-Yasiri, I. B. R. \& Al-Hadrawi, D. A. K. (2018). Effect of growth medium and organic residues extract (compost) extract spray on growth and flowering parameters of Stock (Petunia hybrid). Kufa Journal Agriculture Science, $10,1-23$. http://journals.uokufa.edu.iq/index.php/kjas/article/vi ew/7123

Al-Samaraee, S. M. S.; Hassan, A. O., \& Al-Shoaily, A. N. S. (2011). Effect of spraying yeast suspension, and time of cutting on growth and content of henna plant from Tannins and Lawsone pigment. Journal Basrah Research $\quad$ Science, $\quad 37, \quad 104-$ 115.https://www.iasj.net/iasj?func=article\&aId=5959 4

Bouzabata, A., Casanova, J., Bighelli, A., Cavaleiro, C., Salgueiro, L., \& Tomi, F. (2016). The Genus Myrtus L. In Algeria: Composition and biological aspects of essential oils from $M$. communis and $M$. nivellei: A Review. Chemistry \& Biodiversity, 13, 672-80. https://www. 10.1002/cbdv.201500342

Devlin, R. M., \& Witham F. H. (1993). Plant Physiology. Willard Grant Press, Boston, 435pp. https://0i.is/HwnG

Ebrahimabadi, E. H., Ghoreishi, S. M., Masoum, S., \& Ebrahimabadi, A. H. J. (2016). Combination of GC/FID/Mass spectrometry fingerprints and multivariate calibration techniques for recognition of antimicrobial constituents of Myrtus communis L. essential oil. Chromatography Annals Technology Biomedicin Life Science, 1008, 50-57. https://doi.org/10.1016/j.jchromb.2015.11.010.

Eyras, M. C., Defosse, G. E., \& Dellatorre, F. (2008). Seaweed compost as an amendment for horticultural soils in Patagonia. Argentina, Compost Science and Utilization, 16 ,

119-124. https://doi.org/10.1080/1065657X.2008.10702366

Hajiaghaee, R., Faizi, M., Shahmohammadi, Z., Abdollahnejad, F., Naghdibadi, H., \& Najafi F. (2016). Hydroalcoholic extract of Myrtus communis can alter anxiety and sleep parameters: A behavioral and EEG sleep pattern study in mice and rats. Pharmalogy Biology, 54, 2141-2148. https://doi.org/10.3109/13880209.2016.1148175
Hegazi, H. H., \& Awad, A. M. (2002). Irrigation trickle mineral $\mathrm{N}$ and bio-fertilization effect on potato yield, tuber quality and water use efficiency. Alexandria Journal of Agricultural Science, 47, 89105.https://agris.fao.org/agrissearch/search.do?recordID=EG2004000361

Idris, M. H. (2009). Plant Physiology. Suzan Mubarak Centre Science Exploration, Cairo, 436pp. (In Arabic).https://f.zira3a.net/shoewthread.php?t=23977

Jabri, M. A., Rtibi, K., Ben-Said, A., Aouadhi, C., Hosni, K., \& Sakly, M. (2016). Antidiarrhoeal, antimicrobial and antioxidant effects of myrtle berries (Myrtus communis L.) seeds extract. Journal Pharmcology, 68, 264-274. https://doi.org/10.1111/jphp.12505

Jamshidi-Kia, F., Lorigooini, Z., \& Amini-Khoei, H. (2018). Medicinal plants: Past history and future perspective. Journal Herbmedicin Pharmacology, 7, 1-7. https://doi.org/10.15171/jhp.2018.01

Jensen, E. (2004). Seaweed, fact or fancy: From the organic broadcaster, published by moses the Midwest organic and sustainable education. Agriculture Environment, $\quad 12, \quad 164-170$. https://www.iasj.net/iasj?func=fulltext\&aId=84840

Matroad, S. A. K., Hassan, F. A., \& Kadhim, I. A. (2016). Effect Sowing date and spraying with sea algae extract kelpak on growth, seed and oil yield of basil plant "Ocimum basilicum var. Cinnamon L. Thi-Qar University Journal Agriculture Research, 5, 458-471.

https://www.iasj.net/iasj?func=article \&aId=122543

Salman, J. A., \& Sachet T. F. (2013). Effect of cultivar and Organic Fertilizer and Mowing date on growth and Yield of dill plant (Anethum graveolens L.). Euphrates Journal of Agriculture Science, 5, 291306.

https://www.iasj.net/iasj?func=fulltext\&aId=84950

Reed, G., \& Nagodawithana, W. T. (1991). Yeast technology universal foods corporation Milwaukee. Wisconsin. Published by Van Notre and Reinhold. New York, 273pp. https://link.springer.com/content/pdf/bfm\%3A97894-011-9771-7\%2F1.pdf 
Salih et al./ Basrah J. Agric. Sci., 33 (2): 95-105, 2020

تأثير الرش بالسماد العضوي ALGAZON ومستخلص خميرة الخبز الجافة في بعض الصفات الخضرية لنبات الياس . Myrtus communis L. وحاصله من الزيت الطيار

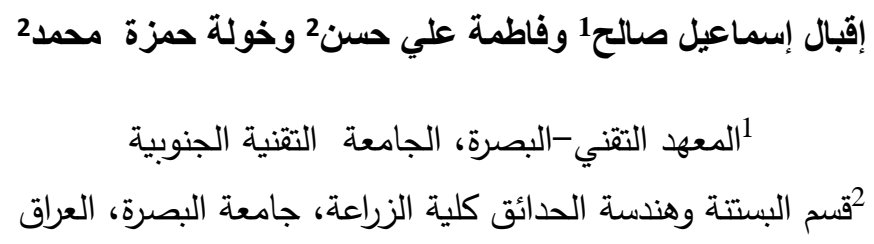

المستخلص: أجريت الدراسة في الظلة القماشية التابعة لمحطة الابحاث الزراعية، كلية الزراعة، جامعة البصرة، موقع كرمة علي

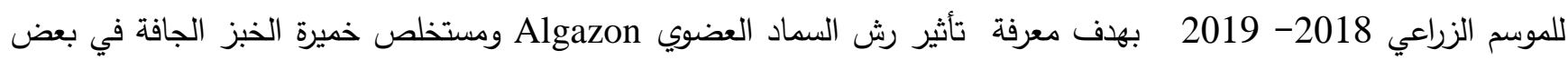
الصفات الخضرية لنبات الياس .Myrtus communs L وحاصله من الزيت الطيار, نفذت الدراسة باستخدام تصميم القطاعات

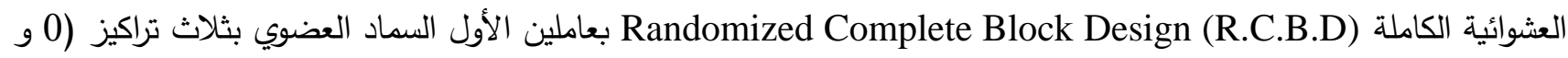

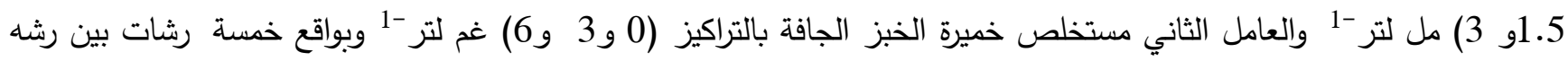
واخرى شهر , واستعمل البرنامج الاحصائي معنوي (L.S.D) على مستوى احتمال 5\% 2. أظهرت النتائج أن الرش بمستخلص السماد العضوي Algazon بتركيز 3مل.لتر 1- أدى الدى الى زيادة معنوية في ارتفاع النبات وقطر الساق الرئيس والمساحة الورقية وعدد الافرع والوزنين الطري والجاف للأوراق والنسبة المئوية

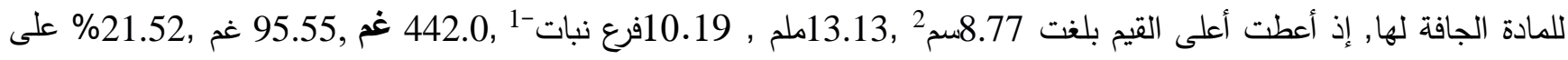
التوالي والنسبة المئوية للزيت وحاصل النبات من الزيت وانتاجية الهكتار من الزيت الطيار ومعامل الانكسار والوزن النوعي وكثافة

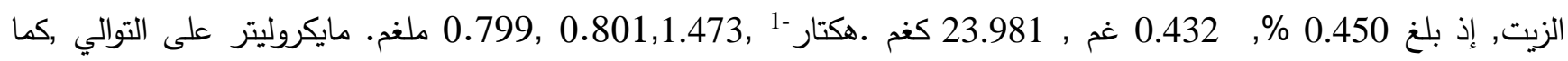

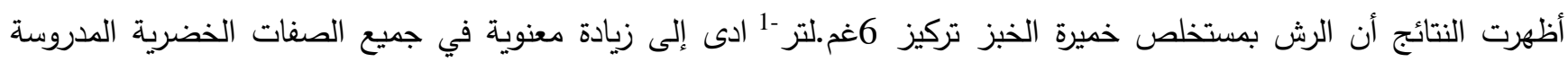

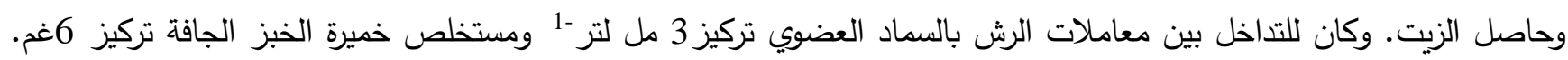
لتر 1- تأثيراً معنوياً , إذ أدى الى زيادة ارتفاع النبات وقطر الساق الرئيس والمساحة الورقية وعدد الافرع الوزنين الطري والجاف للاوراق والنسبة المئوية للمادة الجافة اذ بلغت 21.96\%، على التوالي قياساً بالمقارنة وكذلك أدى الى زيادة النسبة المئوية للزيت وحاصل النبات وانتاجية الهكتار من الزيت الطيار

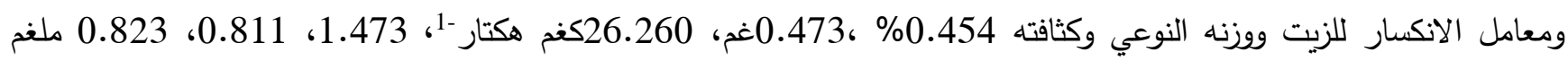
ماكروليتز -1، على التوالي مقارنة بمعاملة المقارنة ,وازداد التأثير كلما زاد التركيز . كلمات مفتاحية: نبات الياس Myrtus communs L , السماد العضوي Algazon, خميرة الخبز, النمو الخضري, الزيت الطيار. 